\title{
我が国における生物多様性保全に関する研究動向
}

\section{Recent Studies on Biodiversity Conservation}

倉本 宣 ${ }^{*}$ 本田裕紀郎** 園田 陽一** 石綿 利光 ${ }^{* *}$ Noboru KURAMOTO Yukio HONDA Youichi SONODA Toshimitsu ISHIWATA

\section{1.はじめに}

生物多様性(biodiversity)の概念は 1980 年代後半になっ て普及したもので，生物界におけるあらゆる階層の変異性 （variety）を意味する包括的概念 ${ }^{40)}$ である。生物的多様性 (biotic diversity)は生物のようなあのの多様性というニュ アンスがあり, 生物学的多様性 (biological diversity)は科 学である生物学によってとらえられた多様性に限定される 危険が指摘されている ${ }^{97)}$ 。生物多様性が意味する内容は, 生物的多様性, 生態的多様性, 遺伝的多様性, 文化的多様 性を含む ${ }^{87)}$ 。ここでは, 主として生態的な階層に準拠して, 遺伝子レベル, 種レベル, 生態系レベル, 景観レベル ${ }^{143)}$ の生物多様性の研究の動向を紹介する。多様性は古くから 生態学のキーワードの一つとなってきたが，ここで対象と した時代は生物多様性の概念が成立した 1980 年代後半以 降である。

\section{2. 生物多様性保全の理念}

生物多様性の価值論には, 従来, ヒトの生存環境や資源 の喪失といった功利的価値論と生物多様性の存在事態の価 值である内在的価值論がある。それに加えて近年，歴史的 価値の視点が導入された

生物多様性の喪失には人間活動の変遷が密接に関連して いる。しかも我が国には二次的な自然が多い。そのため, 人と自然の空間的関係学である造園学は生物多様性保全の 責務を担っている。

科学的に生物多様性の保全を進めるためのステップは 3 つあり, 生物の過去と現在の状況を正確に把握することと, 生物の減少や絶滅を導いている原因を明らかにすることと, 的確で効果的な保全計画を立て実行することである ${ }^{76)}$ 。

\section{3．遺伝子レベルの多様性に関する研究}

集団間の遺伝子構成の差異に関する研究は, 酵素多型を

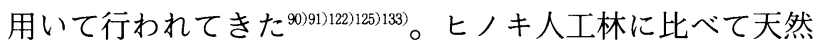
林は高い変異性を内在していること ${ }^{122)}$, クロマッの遺伝
的相違から種苗の交流を差し控えるべき地域（西南日本と 東北日本）が存在すること皇交ざれた。

植栽によって集団間の遺伝子構成が攪乱されることは形 態によって移植されたトベラで示され ${ }^{69)}$ ，植栽手法と遺伝 子レベルの攪乱についての検討が行われている ${ }^{105) 1440}$

遺伝的多様性と集団のサイズには密接な関係があるの で79)，集団の遺伝子レベルの多様性の保全のためには個体 数を維持する必要がある。その際の効率的な保全のために サクラバハンノキの家系構造が解明された ${ }^{899}$ 。

遺伝子レベルの生物多様性の保全に関する研究は蓄積が 少ないが，分子生態学的な手法が急速に進歩しているので, 今後の研究の進展が期待される。

\section{4 、種および個体群レベル}

生物多様性保全においては，上位構造である「群集」・ 「生態系」と，下位構造である「遺伝的多様性」に影響を 与える種レベルでの多様性の保全が要である。

（1）絶滅危惧種の種生態

絶滅危惧種の種生態に関する研究では, 対象とした学術 雑誌の性格を反映して維管束植物と鳥類の研究が格段に多 い。個々の絶滅危惧植物についての研究内容をおおまかに 区分すると，その生活史 ${ }^{61)}$, 生育地特性 ${ }^{20(3)(3)(68)(23) 146)}$, 種子の 発芽特性 ${ }^{65)}$ に関する研究等が行われている。対象植物種は カワラノギク ${ }^{70 \sim 74)}$, フジバカマ ${ }^{20135)}$, サクラソウ ${ }^{142)}$, ヤク タネゴヨウ ${ }^{55)}$ 等 ${ }^{(3) 61168399) 123: 146)}$ が挙げられる。鳥類では, コア

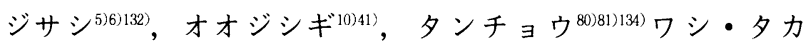
類(4)7733(64)9331199140)をはじめとする絶滅危惧種の生態に関する研

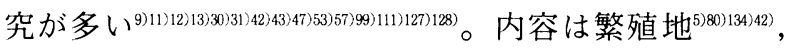
営巣地 ${ }^{5(6) 6493)}$, ねぐら ${ }^{63333)}$ といった生息環境に関する研究事 例が目立つほか，繁殖行動に関する屯の ${ }^{411134}$ が多い。その 他の分類群に関しては, ミヤコタナゴ1778), エゾナキウサ ギ(3)，等 ${ }^{157}$ に関する研究が挙げられる。

絶滅危惧種をめぐる生物間相互作用の解明は絶滅の進行 をさせないためには重要である。小笠原諸島における植物

*明治大学農学部 ${ }^{* *}$ 明治大学大学院農学研究科 
と訪花昆虫のパートナーシップの崩壊 ${ }^{60)}$, 菌類のレッドデー タブックに㧍ける環境共生（植物あるいは動物が関与した 環境を保全する) $)^{98)}$ の研究事例がある。

遷移や捕食者との関係から, 動態を扱う研究が求められ ており, メ夕個体群の動態が格子モデルで検討されてい る ${ }^{121}$ 。また, 絶滅危惧度については, 本特集で井上が論じ ているが，マグロを事例とした検討がある ${ }^{1473} 。$

（2）帰化生物

䚻化生物に関する研究事例としては，その分布に関して， アメリカコナギ ${ }^{86)}$, コカナダモ ${ }^{102)}$, タウナギ85) 等 ${ }^{(10)(26)}$ の研 究が挙げられる。また，生態系への影響を論じたものでは， シナダレスズメガヤ ${ }^{100)}$ ，二セアカシア ${ }^{77)}$ が，挙げられる。 帰化生物は意図的に持ち込まれる場合と，非意図的に持ち 込まれる場合がある。法面緑化に用いられる牧草には帰化 植物となっている種が含まれており, 生態系に与える影響 が憂慮されている ${ }^{1411}$ ので, 解決するための技術の構築と社 会的な合意形成が待たれている。

(3) 移植・導入

移植・導入に関しては，十勝川水系におけるバイカモ七委 の他, 飼育繁殖させたダルマガエルを個体群へ導入した研 究例 ${ }^{106)}$ がある。

研究対象種は我が国のレッドデータ種のごく一部に過ぎ ない。これまで研究には一般則が求められることが多かっ たが，個別の種の生態を明らかにすることが絶滅危惧種全 体の保全のためにも必要である。

\section{5. 群集・生態系レベル}

この分野の研究法を検討したものには鳥類群集の調査 法 $^{116)}$, 多様度指数 ${ }^{51162(95)}$ があげられる。

(1) 植生管理

生物多様性の保全に関する植生管理については, 研究の 目的により「野生草花の保全」,「種多様性の確保」,「帰化 植物に対する管理手法」とに区別できる。「野生草花の保 全」に関しては, 適切な植生管理手法 ${ }^{108) 1093117) 1181200}$, 生育地 の保全のための植生管理 $\left.{ }^{107}{ }^{146}\right)$ (150), 遺伝資源保存を目的とす る植生管理 ${ }^{130)}$, 目標林床景観の創造 ${ }^{48}$ などが挙げられる。 「種多様性の確保」を目的としたものには，植生管理の与 える影響3)(52)153)，伝統的な管理手法の検討 ${ }^{52}{ }^{1177}{ }^{1182}$ ，植生管 理と種多様性の関係 ${ }^{(1) 138) 151)}$ がある。刚り取りの時期, 頻度, 強度などが, 重要な要素になっていることが明らかになっ た。「帰化植物に対する管理手法」では，河原で優占する ようになったオオブタクサの種特性に配慮した管理 ${ }^{92)}$ が提 案されている。

（2）植生復元

復元事業には水域に生育する植物について地域に特有で 生物多様性保全の条件を網羅している浚渫土を用いた研究 報告 ${ }^{44) 110)}$ がある。また, 谷戸植生, 河畔冠水草原植生を対
象としたものは，土袞シードバンクを用いた実験的検 証 $^{45667}$ により，より効率的な植生復元が可能となった。

(3) アセスメントとミティゲーション

最近, 改正された環境アセスメント制度の中で, 生物多 様性の保全が検討されている ${ }^{83)}$ 。開発の生態系に与える影 響については湿原に与える影響が調査されている ${ }^{145)}$ 。

生態系を実質的に保全するため, ミティゲーションの概 念と手法を積極的に導入しようという動きが活発になって きた。1990年代後半から, ビオトープの創出と評価 ${ }^{137}$, ビオトープ計画のための土地的環境ポテンシャル評価手 法年), 生態学的立地区分から見たビオトープ計画25)など, 計画対象地のビオトープ造成適正を評価する研究が行われ るようになった。また, 特定の保全対象種を視野に入れた ビオトープ造成計画地の選定と計画の再検討 ${ }^{66)}$ ’，鳥類の 潜在的生息地図化之湿地植生計画のためのシナリオ分析 ${ }^{27)}$ によってこの分野の実現可能性が示された。

\section{6. 景観レベルでの生物多様性の保全に関する研究}

1990 年以降, 種・個体群や群集・生態系レベルでの研 究に加え, 景観レベルでの研究が行われるようになった。 生物多様性の上位の階層を成す「景観」の概念は, 物理的 な環境としての地形と植生を含む生物群集の相互作用系と してとらえられている ${ }^{1433}$ 。しかし，動植物のハビタットは 森林伐採, 道路・鉄道建設, 宅地開発等の人間活動による 影響により面積の縮小, 分断化, 孤立化が進行し, 生物多 様性の減少を引き起こしている。

（1）分断化，孤立化

ハビタットの孤立化，分断化が植物にもたらす影響につ いて, 孤立林間で他殖型植物の結果率を比較し結果率に与 える林外環境と開花時期におけるポリネーターが結果率に あたえる影響の評価 ${ }^{154)}$ や孤立林と非孤立林においてアリ類 の出現種類数, 種組成を指標とした林内の節足動物相 ${ }^{18)} お$ よび各孤立林の面積の関係 ${ }^{18)}$ ならびに小笠原諸島を含む地

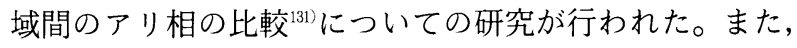
ニュータウン開発に伴う残存林 ${ }^{19}$ や照葉樹林からなる社寺 林 ${ }^{46)}$ などの孤立林の面積と出現種数の関係を鳥嶼生物地理 学的な観点から明らかにした研究事例では, 種数一面積関 係から多様な生物の生育・生息に必要な孤立林の保全面積 への提案を行っている。

\section{(2) 景観要素}

ランドスケープエコロジーは，空間単位の「垂直的関係」 と空間単位の「水平的関係」の両方を理解する研究分野で あるとされている ${ }^{129)}$ 。このようなンドスケープエコロジー の観点から都市や農村地域における鳥類の分布と土地利用 の関係 ${ }^{(5) 16336) 54)}$ ，チョウ類の種組成と土地利用の関係 ${ }^{101)}$, サ シバの分布と谷津環境の関係 ${ }^{4)}$, カエル類の生息状況と谷 戸田の関係 ${ }^{133}$, 水域の形状と珪藻群集の種組成の関係 ${ }^{59)}$, 
水田・畦畔植生と谷津田の土地利用の関係 ${ }^{2)}$, シュレーゲ ルアオガエルの生息と環境条件の関係 ${ }^{115)}$, 生物相と生態系・ ランドスケープの変化を比較することによる生物多様性の 変化要因 ${ }^{28)}$ な゙環境条件の水平構造と生物の分布や種組成 の関係についての研究が行われてきた。また, ハビタット の植生の構造・種組成と生物の分布の関係を明らかにする

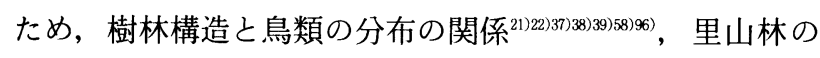
構造と林床植物の関係 ${ }^{149)}$, 湿性緑地の植生構造とトンボの 対応関係 ${ }^{112)}$ など5682), 環境条件の垂直的な構造と生物の分 布や種組成との関係を明らかにした研究が見られるように なった。

（3）エコロジカルネットワーク

1990 年代後半では, エコロジカルネットワークの研究 が盛んになった ${ }^{35)}$ 。オランダにおけるエコロジカルネット ワーク計画の理論的背景, 計画内容, 実務戦略と生態イン フラストラクチャー整備状況年) やエコロジカルネットワー ク計画を実現するための計画プロセス ${ }^{26)}$ が示され, 我が国 におけるエコロジカルネットワーク計画を実務レベルに発 展させようとする気運がある。また, 谷戸の特性とエコロ ジカルネットワーク形成によるカエル類の保全 ${ }^{114}$ のように エコロジカルネットワークを都市域における生物多様性の 保全を目的とした緑地計画に取り入れようとする動きが見 られる。

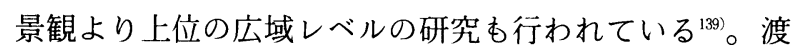
り鳥にとっては地球レベルのエコロジカルネットワークの 確保が重要であり ${ }^{7)}$, その研究方法が開発されている ${ }^{23)}$ 。

（4）生物多様性保全のために重要な地域

我が国におけるそれぞれの地域が固有の生物相を育んで きたのでかけがえのないものであり，保全の対象となる。 特に生物多様性の上での危機が論じられていた重要な地域

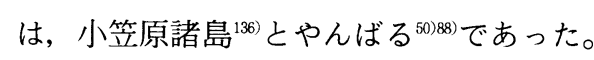

\section{7. 将来に向けて}

(1) 制度の検討

生物多様性保全に関わる制度の検討は，法制度 ${ }^{49}$ ，保護 林制度 $\left.{ }^{155} 156\right)$, 鳥獣保護および狩猟制度 ${ }^{124}$, アセスメント ${ }^{83)}$, ミティゲーションとミティゲーションバンキング(4) につい ての研究があり, 生物多様性保全を実効のあるものにする ために欠かせない研究である。生物多様性国家戦略が実効 をあげていないのは，他の政策よりも生物多様性の保全を 優先させるという政治的決断を明確に行っていないこと, 省庁間の調整，市民参加の政策づくりのシステムの欠如で ある ${ }^{8)}$ 。生物多様性の保全を真に成功させるには, 人間の さまざまな活動にかかわる分野への政策を関連させた総合 的な政策が必要である ${ }^{75)}$ 。

(2) 市民

現代の日本において生物多様性の保全を実行あるあのに するためには, 政府であなく企業であない立場で取り組む 勢力, 科学的知識と草の根運動をつなぐ情報センター, 政 策対話のできる開かれた仕組み, 民間の非営利で独立した 立場で政策研究のできる人材之組織, 政府や企業之は違っ た立場で海外の人々と交流できる人材と組織を育てる とが待たれている。

(3) 科学者・技術者

欧米では研究と保護活動は緊密に結びついているが，我

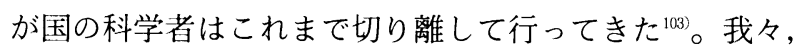
造園家は保全のための実務の中に, たくさんの研究的な課 題をみいだすことができる。その課題の解明を通じて, 次 の時代の視点を構築することが求められている。

\section{引用文献}

1）赤井裕（1997）：田んぼとともに生きて きたミヤコタナゴ：科学 67(10), $756-758$

2) 有田ゆり子・小林達明（2000）: 谷津田 の土地利用変化と水田・畦畔植生の特性 : ランドスケープ研究 63(5), 485-490

3 ）浅見佳世・服部保・赤松弘治（1995）: 河川堤防植生の刚り取り管理に関する研 究: ランドスケープ研究 58(5), 125-128

4 ) 東淳樹・武内和彦・恒川篤史 (1998): 谷津環境におけるサシバの行動と生息条 件: 第 12 回環境情報科学論文集, 239-244

5 ) 東陽一 (1998)：コアジサシの営巣環境 条件と集団繁殖地の保全策 : ランドスケー プ研究 61(5), 541-544

6 ）東陽一・桑原和之・金井裕（1996）：コ アジサシ Sterna albifrons の営巣地の
現状と保全策 : Strix 14, 143-157

7 ) 鄭鐘列・樋口広劳・朴宇日（1992）：朝 鮮半島におけるッル類の渡りの経路之重 要中継地一人工衛星による追跡調査の結 果一Strix 11, 21-34

8 ）堂本暁子 (1997)：国政の場でなにが議 論されたのか：科学 67(10), 707-709

9 ) 藤巻裕蔵 (1993)：北海道十勝地方にお けるオシドリの生息状況：Strix 12, $171-176$

10）藤巻裕蔵（1994）：北海道南東部におけ るオオジシギの生息状況：Strix 13, 73-78

11）藤巻裕蔵・藤田剛・柚木修 (1990)：ソ 連極東ビキン川流域におけるコウノトリ の繁殖生態 -1990 年日ソ希少鳥類共同 調査 - : Strix 9, 139-157

12）藤巻裕蔵・花輪伸一・尾崎清明（1989）: ソ連極東ビキン川流域におけるナベッ゙ル
の繁殖生態-1990 年日ソ希少鳥類共同 調查一：Strix 8, 199-217

13）藤波不二雄（1983）：ヨシ原の面積と才 オョシキリの囀り雄の個体数との関係 :

Strix 2, 41-46

14）深町加津枝 - 奥敬一 - 下村彰男 - 熊谷洋 一・横張真（1999）：京都府上世屋・五 十河原地区における里山ブナ林の管理手 法と生態的特性：ランドスケープ研究 62(5), 687-692

15）福井亘・近藤公夫 - 安部大就 - 増田昇 （1997）：神戸市西区の都市近郊農村にお ける農村環境と鳥類生息に関する研究 : ランドスケープ研究 60(5), 553-556

16）福井 亘・増田昇・安部大就（1998）: 西神戸と東播磨地区における農地の存在 形態と鳥類生息との関連に関する研究 : ランドスケープ研究 61(5), 545-550

17）花輪伸一・柚木修・山田元一郎（1990）: 
ソ連極東ウディル湖岸におけるオオワシ の繁殖生態 -1989 年日ソ希少鳥類共同 調査一：Strix 9, 219-232

18）橋本佳明・上甫木昭春・服部 保 (1994): アリ相を通してみたニュータウン内孤立 林の節足動物相の現状と孤立林の保全に ついて：造園雑誌 57(5), 223-228

19）服部保・上甫木昭春・小舘哲治・熊懐恵 美・藤井俊夫・武田義明（1994）：三田 市フラワータウン内孤立林の現状と保全 について：造園雑誌 57(5), 217-222

20）服部保 - 田村和也 -小館誓治（2000）: フジバカマ生育地の現状と保全 : ランド スケープ研究 63(5)，477-480

21）葉山嘉一（1994）：都市緑地における鳥 類の生息特性に関する研究：造園雑誌 57(5), 229-234

22）葉山嘉一・高橋理喜男・勝野武彦 (1996): 都立東大和公園における植生と鳥類の生 息特性に関する研究：ランドスケープ研 究 59(5), 89-92

23）樋口広芳・森下英美子（1997）：野生動 物保全の新しい試み：生物科学 49(2), 84-94

24）日置佳之（1996）: オランダにおける国 土生態ネットワーク計画とその実現戦略 に関する研究 : ランドスケープ研究 59(5), 205-208

25）日置佳之・藤原宣夫・水谷義昭・浅野文・ 田中真澄・太田望洋（1999）：湿地植生 計画のための生態学的立地区分に関する 研究: ランドスケープ研究 62(5), 607-612

26）日置佳之・井手佳季子（1997）：オラン ダの 3 つの生態ネットワーク計画の比較 による計画プロセスの研究 : ランドスケー プ研究 60(5)，501-506

27）日置佳之・百瀬浩・水谷義昭・松林健一・ 鈴木明子・太田望洋（2000）：湿地植生 計画のための鳥類の潜在的生息地図化之 シナリオ分析に関する研究 : ランドスケー プ研究 63(5), 759-764

28）日置佳之・須田真一・百瀬浩 - 田中隆 松林健一・裏戸秀幸・中野隆雄・宮畑貴 之 (2000): ランドスケープの変化が種 多様性に及ぼす影響に関する研究一東京 都立石神井公園周辺を事例として一：保 全生態学研究 5(1), 43-69

29）日置佳之 - 田中隆 - 塚本吉雄 - 田中真澄 裏戸秀幸・養父志乃夫（1998）：湿地ビ オトープ計画のための土地的環境ポテン シャル評価手法に関する研究 : ランドス ケープ研究 61(5), 523-528

30) 平井正志 (1999): 三重県中部河川での イカルチドリの繁殖 : Strix 17, 77-83

31）平井正志・橋本富三・西村泉・坂口守・
大西幸枝・中村洋子・橋本祐子・秋田由 美子 (2000): 三重県中部の自然海岸に おけるシロチドリの繁殖：Strix 18, $45-53$

32)平川浩文・樋口広芳（1997）：生物多様性 の保全をどう理解するか：科学 67(10), 725-731

33）平野敏明・遠藤孝一・君島昌夫・小堀政 一郎・野中純・内田裕之（1998）：渡良 瀬遊水地に扔ける秋冬期のチュウ七の稀 ぐら: Strix 16, 1-15

34）星野義延・星野-今給黎順子（1995）：都 市環境下における危急植物トキホコリの 生態：野生生物保護 1(1), 13-20

35）一ノ瀬友博・Hotes, Stefan (1997)：ド イッにみる生態的ネットワークを生かし た国づくり：科学 67(10), 772-778

36）一八瀬友博・加藤和弘（1993）: 都市及 び農村地域に沶ける鳥類の分布と土地利 用の関係について：造園雑誌 56(5)， 349-354

37）一入瀬友博・加藤和弘（1994）：埼玉県 所沢市の孤立樹林地における鳥類群集の 分布に影響を及ぼす諸要因について：造 園雑誌 57(5)，235-240

38）一八瀬友博・加藤和弘（1996）：埼玉県 所沢市の孤立樹林地における越冬期の鳥 類分布と植生構造との関係 : ランドスケー プ研究 59(5), 73-76

39）一八瀬友博 - 加藤和弘（1999）：武蔵野 台地および狭山丘陵の樹林地における鳥 類の分布之植生の種組成の関係について : ランドスケープ研究 62(5), 577-580

40）井手久登・亀山章（1993）：緑地生態学: 朝倉書店

41）飯田知彦 (1991): オオジシギ Gallinago hardwickii の繁殖行動と生 息環境 : Strix 10, 31-50

42）飯田知彦（1992）：電柱を営巣場所にす るブッポウソウ Eurystomus orientalis の繁殖分布：Strix 11, 99-108

43）飯田知彦・田中晋（1990：ノビタキの 生態と保護に関する一考察：Strix 9, 43-54

44）池田佳子・荒木佐智子・村中考司・就谷 いづみ（1999）: 浚渫土を利用した水辺 の植生復元の可能性の検討 : 保全生態学 研究 4(1), 21-31

45）今橋美千代・鷲谷いづみ（1996）：土壤 シードバンクを用いた河畔冠水草原復元 の可能性の検討 : 保全生態学研究 $1(2$ 3), 131-147

46）石田弘明・服部 保 - 武田義明 - 小舘誓 治 (1998)：兵庫県南東部における照葉 樹林の樹林面積と種多様性・種組成の関 係 : 日本生態学会誌 $48,1-16$
47）石田健・高美嘉男（1998）：アマミヤマ シギの相対生息密度の推定 : Strix 16, 73-88

48）石井正人 - 中越信和（1997）：森林公園 計画における二次林の林冠木個体群構造 と植生管理に関する研究 : ランドスケー プ研究 60(5), 543-546

49）磯崎博司（1997）: 生命支持システムを 守るための法制度：科学 67(10), 799-804

50）伊藤嘉昭（1997）：沖縄やんばるの森の 生物多様性 : 科学 68(11)，885-894

51）伊藤秀三（1995）：垂直分布にみる植生 のベー夕多様性：日本生態学会誌 45 , 99-111

52）伊藤貴庸・中山祐一郎・山口裕文 (1999)： 伝統的畦畔と基盤整備畦畔における植生 構造とその変遷過程: 雑草研究 44(4), 329-340

53）岩崎由美・市石博（1998）：伊豆大島 ・ 利島に扔けるカラスバトの悋ぐら：

Strix 16, 89-98

54）ジョンボスコジョロゲ・福井亘・森本 幸裕（2000）：万国博記念公園における 夏季鳥相におよぼす土地被覆の影響 : ラ ンドスケープ研究 63(5), 501-504

55）金谷整一・玉泉幸一郎・伊藤哲（1997）： 屋久島破沙岳におけるヤクタネゴョウの 分布様式：日本林学会誌 79(3), 160-163

56）金本自由生（1997）：女川湾及び仙台湾 に掞ける磯の空間的構造と磯魚群集の種 多様性, 垂直分布及び現存量 : 日本生態 学会誌 $47,11-20$

57）片岡義廣・水野政巳（1999）：北海道浜 中町霧多布におけるエトピリカの生態之 生息数変動 : Strix 17, 1-14

58）加藤和弘（1996）: 都市緑地内の樹林地 における越冬期の鳥類と植生の構造の関 係: ランドスケープ研究 59(5), 77-80

59）加藤和弘（2000）：河川における付着珪 藻群集の多様性之水域形状の関係: ラン ドスケープ研究 63(5), 523-526

60）加藤真 (1997)：植物をめぐるパートナー シップの成立と崩壊：科学 67(10), 633-640

61）木村保夫・鈴木正幸・大野啓一・高久景 一 (1999)：タコノアシの生活史と異な る水分条件に対するその成長特性 : 水草 研究会会報 66, 15-18

62）小林四郎 (1981)：多様性指数：サンプ ル・サイズと空間分布に対する関係 : 日 本生態学会誌 31(3), 231-236

63）小島望（1999）：然別湖湖畔トンネル建 設後のエゾナキゥサギの消滅 : 野生生物 保護 4(1), 17-27

64）小島幸彦（1992）：新潟県魚沼地方にお 
いて岸壁営巣するノスリButeo buteo の営巣環境 : Strix 11, 91-98

65）近藤哲也・山口真有美（1999）：海浜植 物の保全と景観への利用を目的とした八 マエンドウの種子発芽特性 : ランドスケー プ研究 62(5), 507-510

66）近藤俊明・中越信和・谷本茂（1999）: 広島大学キャンパス内の小河川における ビオトープ計画の景観生態学的評価 : ラ ンドスケープ研究 62(5), 603-606

67）越水麻子・荒木佐智子・整谷いづみ・日 置佳之・田中隆・長田光世（1997）：土 壤シードバンクを用いた谷戸植生復元に 関する研究：保全生態学研究 2(3), 189-200

68）倉本宣（1984）：都市公園におりる春植 物ニリンソウ保全のための基礎的研究 : 造園雑誌 47(5), 101-105

69）倉本宣（1986）：伊豆諸島のフロラ特性 とそれに対応した植栽手法：応用植物社 会学研究 15，17-24

70）倉本宣・石濱史子・熟谷いづみ・嶋田正 和 - 可知直毅 - 井上健 - 加賀屋美津子 牧雅之・竹中明夫・増田理子（2000）: 多摩川のカワラノギク保全のための緊急 アピール：保全生態学研究 5(2), 193196

71）倉本宣 - 加賀屋美津子 - 可知直毅 - 井上 健 (1997)：カワラノギクの個体群構造 と実生定着のセーフサイトに関する研究： ランドスケープ研究 60(5), 557-560

72）倉本宣・竹中明夫・鷲谷いづみ・井上健 (1992)：多摩川におけるカワラノギクの 保全生物学的研究：造園雑誌 55(5), 199-204

73）倉本宣・熟谷いづみ・井上健（1995）: 多摩川におけるカワラノギクの個体群の 分断化とその保全における種子散布の役 割：造園雑誌 55(5), 113-116

74）倉本宣・熟谷いづみ・牧雅之・増田理子・ 井上健（1994）：多摩川におけるカワラ ノギクの種子期の動態 : ランドスケープ 研究 57(5), 127-132

75）黒坂三和子（1997）：国際 NGO による 政策提言: 科学 67(10), 790-798

76）前田环（1997）：失われゆく生物多様性 と人間の責務 : 科学 67(10), 732-739

77）前河正昭・中越信和（1997）：海岸砂地 において二セアカシア林の分布拡大があ たらす成帯構造と種多様性への影響 : 日 本生態学会誌 47, 131-143

78）真板昭夫・海津ゆりえ・下村彰男・首藤 正隆（1999）：ミヤコタナゴの生息に必 要な里地環境と管理体系の変遷 : ランド スケープ研究 62(5), 681-686

79）牧雅之・增田理子（1997）：生物集団の
遺伝的多様性の減少：科学 $67(10)$, 641-648

80）正富宏之（1988）：十勝地方における夕 ンチョウの繁殖地とその個体群の越冬地 : Strix 7, 239-248

81）正富宏之・百瀬邦和・百瀬ゆりあ・松尾 武芳・古賀公也・青木則幸・安部誠典・ 井上雅子・金井裕（1994）：1994 年の北 海道東部におけるタンチョウの繁殖状況 : Strix 13, 103-142

82）増山貴一・藤崎健一郎・勝野武彦（1998）： 神奈川県高麗山における植生の違いによ るセミ類の種構成の差異 : ランドスケー プ研究 61(5), 535-540

83）松田裕之（1998）：愛知万博が突きつけ た環境影響評価法の問題点: 科学 68(8), 632-636

84）松井宏明・佐々木英代（1997）：十勝川 水系におけるバイカモ(キンポウゲ科)移 植の試み: 水草研究会会報 $60,1-6$

85）松本清二・永井伸夫 - 今西塩一・蓮池宏 一・幸田正典（1998）：奈良県及びその 周辺域での移入魚タウナギの分布拡大： 日本生態学会誌 48, 107-116

86）松尾光弘・芝山秀次郎（1997）: 侵入か ら約 20 年を経過した 1995 年の岡山県南 部の水田におけるアメリカコナギの分布 : 雑草研究 42(3)，221-226

87）三中信宏（1997）:外なる多様性，内なる 多様性 : 生物科学 49(2), 57-59

88）宮城邦治（1997）：ヤンバルの森は守れ るか: 科学 67(10), 754-755

89）宮本尚子・山本徳子・星比呂志 (2000): アイソザイムによる茨城県十王町サクラ バハンノキ集団の家系構造 : 日本林学会 誌 82(1), 72-79

90）宮田增男・生方正俊（1993）：シラベお よびウラジロモミのアイソザイムの遺伝 : 日本林学会誌 75(4), 356-360

91）宮田増男・生方正俊（1994）：クロマッ 天然生林におけるアロザイム変異 : 日本 林学会誌 76(5), 445-455

92）宮脇成生・熟谷いづみ（1996）：土壤シー ドバンクを考慮した個体群動態モデルと 侵入植物オオブタクサの駆除効果の予測 : 保全生態学研究 1(1)，25-47

93）森本栄・飯田知彦（1994）：広島県西部 におけるクマタカSpizaetus nipalensis の営巣環境: Strix 13, 179-190

94）森本幸裕・村田辰雄・大西正記（1998）: ミティゲーションとミティゲーションバ ンキング：日本緑化工学会誌 23(4), 256-262

95）森下正明（1996）: 種多様性指数値に対 するサンプルの大きさの影響 : 日本生態 学会誌 46, 269-289
96）森田健吾・葉山嘉一（2000）：丘陵地の 植生構造が繁殖期の鳥類に及ぼす影響に ついて：ランドスケープ研究 63(5), 505-508

97）本谷熏（1993）：生物の多様性：生物科 学 45(1), 6-9

98）長尾英幸（2001）：菌類の絶滅はどこま で進んでいるか: 科学 71(3)，256-263

99）中村充博・由井正敏・鈴木祥悟（1995）: 南八甲田地域のクマゲラの行動圏とその 植生構造：野生動物保護 $1(3 / 4)$, 153-157

100）中坪孝之（1997）：河川氾濫原における イネ科帰化草本の定着とその影響 : 保全 生態学研究 2(3), 179-187

101）夏原由博（2000）:都市近郊の環境傾度 に沿ったチョウ群集の変化 : ランドスケー プ研究 63(5), 515-518

102）野原精一（1988）: 尾瀬沼と湯の湖にお けるコカナダモの生態 : 水草研究会会報 $33 \cdot 34,43-46$

103）小原秀雄（1985）：内外に打ける野生生 物保護の現代的動向：生物科学 37(3), $132-135$

104）小川潔・本谷勲（1985）：東京圈におけ る外来種タンポポの侵入と在来種タンポ ポの残存：日本生態学会誌 $35(4)$, 443-452

105）奥津慶一・倉本宣（1999）：伊豆大島愛 宕山へのスダジイ移植の検討のための遺 伝的変異の解析 : ランドスケープ研究 62(5), 533-538

106）大河内勇・宇都宮妙子・宇都宮泰明 沼澤マヤ (1997)：ダルマガェル (Rana porosa brevipoda Ito)の岡山種族の飼 育下での繁殖と絶滅が危惧された個体群 への補強的な再導入: 保全生態学研究 2(2), 135-146

107）大窪久美子 - 前中久行（1990）：野生草 花の生育地の保全を目的とした半自然草 地の遷移診断 : 造園雑誌 53(5), 145-150

108）大窪久美子・前中久行（1992）：クマイ ザサ優占群落における野生草花の保全を 目的とした時期を変えた刈取りの影響： 造園雑誌 55(5)，193-198

109）大窪久美子 - 前中久行（1993）：野生草 花の保全を目的としたクマイザサ優占群 落における刈取り管理に関する研究 : 造 園雑誌 56(5)，109-114

110）大村理恵子・村中考司・路川宗夫・䲼 谷いづみ（1999）：霞ヶ浦の浚渫土まき だし地に成立する植生 : 保全生態学研究 4(1), 1-19

111）大迫義人・長野義春・西田智（1990）: 出水・阿久根地方で越冬するッル類の昼 間の分布の経時変化と調査方法 : Strix 


\section{9, $77-88$}

112）長田光世 - 飯島 博 - 守山弘（1997）: 湿性緑地の植生構造とトンボの対応関係 に関する基礎的研究：ランドスケープ研 究 60(5)，547-552

113）大澤啓志・勝野武彦（1997）：力エル類 を用いた都市域谷戸田の環境分析・評価： 第 11 回環境情報科学論文集, 237-242

114）大澤啓志・勝野武彦（1998）：流域単位 からみた谷戸の特性とカエル類保全に関 する考察：ランドスケープ研究 61(5), 529-534

115）大澤啓志・勝野武彦（2000）：多摩丘陵 南部におけるシュレーゲルアオガエル生 息の環境条件の把握と保全に関する考察 : ランドスケープ研究 63(5)，495-500

116）佐藤重穂・黒岩哲夫（2000）：森林性鳥 類の生息種・密度調査におけるロードサ イド・テリトリーマッピング法の有効性 : Strix 18, 89-98

117）関岡裕明 - 下田路子 - 中本学（2000）: 中池見における水田雑草保全の取り組み一 3 年間のまとめ一：水草研究会会報 71 , 10-16

118）関岡裕明 -下田路子 - 中本学・水澤智・ 森本幸裕（2000）：水生植物および湿性 植物の保全を目的とした耕作放棄水田の 植生管理 : ランドスケープ研究 63(5), 491-494

119）柴田匡敏・伊藤正美・青木進（1991）: 大規模送電線工事がイヌワシにおよぼす 影響一生息地放棄のメカニズム：Strix 10, 115-126

120）重松敏則・高橋理喜男・鈴木尚（1985）: 二次林林床における光条件の改良が野生 ツッジ類の着花に及ぼす効果 : 造園雑誌 48(5), 151-156

121）嶋田正和（1997）：䚍乱を受けるパッチ 状環境での植物と植食性昆虫: 科学 67(10), 662-671

122）白石進・上中久子・大山浪雄（1987）: ヒノキの二つのアイソザイム遺伝子座に おける遺伝的变異之分化: 日本林学会誌 69(3) $88-93$

123）静岡県立静岡高等学校生物部（2000）: 安倍川下流域(静岡市)のミクリ類 : 水草 研究会会報 70,1-14

124）東海林克彦（2000）: 我が国の鳥獣保護 及び狩猟制度における鳥獣保護の考え方 とその変遷に関する研究 : ランドスケー プ研究 63(5)，379-384

125）陶山佳久・津村義彦・大庭喜八郎（199 2) : オオシラビソのアイソザイムの遺伝 および 3 地域の隔離天然林におけるアロ
ザイム変異 : 日本林学会誌 74(2), 65-73

126）鷹見達也・青山智哉（1999）：北海道に おけるニジマスおよびブラウントラウト の分布：野生生物保護 4(1)，41-48

127）武下雅文・佐本一雄・林修（1993）：福 岡県曽根干潟におけるズクロガモメの越 冬数の年変化と季節变化 : Strix 12 107-114

128）武下雅文・佐本一雄・武石全慈（1994）: 福岡県曽根干潟におけるックシガモ Tadorna tadornaの越冬数の年変化と 季節変化 : Strix 13, 53-63

129）武内和彦（1991）：地域の生態学：朝倉 書店

130）武内和彦・暒浦一郎・大黒俊哉（1989）: 野生果樹遺伝資源の現地保存と自生地の 植生管理：造園雑誌 52(5), 151-156

131）寺山守 (1997)：多様性保護の視点から の環境保全：生物科学 49(2), 75-83

132）鳥羽悦男（1994）：長野県犀川执よび千 曲川のコアジサシ Sterna albifrons の 営巣地の減少とその保護：Strix 13, 93-101

133）戸丸信弘・津村義彦・大庭喜八郎（199 0)：チョウセンゴョウのアイソザイムの 遺伝 : 日本林学会誌 72(3), 194-20

134）富岡辰先・高橋巧一・樋口広芳 (1990): 繁殖地におけるタンチョウの行動と湿原 の利用状況 : Strix 9，31-42

135）富沢美和・鷲谷いづみ（1998）：フジバ カマとセイタカアワダチソウの夏季にお ける地上部喪失に対する反応一復元植生 の管理計画を立てるために一：保全生態 学研究 3(1),57-67

136）富山清升（1997）:日本の地域自然破壊 とその保護の現状：生物科学 49(2), 68-74

137）土田勝義・塩原明彦・高山光弘（1997）: 農村地域におけるビオトープブくりとそ の評価：環境情報科学 26(4), 49-55

138）辻誠治・星野義延（1992）：コナラ二次 林の林林管理の変化が種組成と土壌に及 ぼす影響：日本生態学会誌 $42(2)$, 125-136

139）恒川篤史（1997）: 広域モニタリングの 現状と将来 : 科学 67(10), 765-771

140）植田睦之・小板正俊・福井和二 (1999)： 秋期のオオワシとオジロワシの分布影響 する要因 : Strix 17, 25-29

141）敦谷いづみ（2000）: 生物多様性を脅か す「緑の」生物学的侵入：生物科学 $52(1), 1-6$

142）鷲谷いづみ（1997）: 植物の保全生態学 の今 : 生物科学 49(2), 61-67
143）犚谷いづみ・矢原徹一（1996）：保全生 態学入門 : 文一総合出版

144）渡辺幹男・芹沢俊介・菅沼孝之（1996）: 大台ヶ原に他地域のトウヒを持ち込んで もよいのか?: 植生学会誌 13(2), 107110

145）矢部和夫・中村隆俊・河内邦大（1999）: 排水路と国道がミズゴケ湿原に与えた影 響：ランドスケープ研究 62(5), 557-560

146）養父志乃夫・重松敏則・高橋理喜男（1 985）：カタクリ群落の保全管理に必要な 生態的諸条件：造園雑誌 48(5), 157-162

147）矢原徹一・松田裕之・魚住雄二 (1996): マグロは絶滅危惧種か：科学 66(11), 775-781

148）山口裕文・梅本信也・前中久行（1998）: 伝統的水田と基盤整備水田における畦畔 植生: 雑草研究 43(3), 249-257

149）山本勝利・趙 賢一 - 大塚生美 - 福留晴 子・加藤好武・大久保悟 (2000)：比企 丘陵における里山林の構造と変化が林床 植物に及ぼす影響: ランドスケープ研究 63(5), 765-770

150）山本勝利・加藤好武・横張真（1998）: 春植物群の生育から見た中山間地におけ る森林の林分構造と立地：ランドスケー プ研究 61(5), 557-562

151）山崎寛・青木京子・服部保 - 武田義明 （2000）：里山の植生管理による種多様性 の増加：ランドスケープ研究 63(5), 481-484

152）山瀬敬太郎（1998）: アカマッ二次林に おける下層木伐採程度の差によるその後 の植生比較：ランドスケープ研究 61(5), 567-570

153）山戸美智子・服部保（2000）: 六甲山系・ 東お多福山草原の現状々管理手法 : ラン ドスケープ研究 63(5), 473-476

154）八坂通泰・須永由紀・川崎文主・紺野 康夫 (1994) : 森林の孤立化が 3 種の多 年草の結果率にあたえる影響 : 日本生態 学会誌 $44,1-7$

155）安原加津枝・中静透・長江恭博 - 熊谷 洋一（1993）: 保護林制度にみる森林の 保護管理の変遷：造園杂隹誌 56(5), 187-192

156）安原加津枝・奥敬一・田中伸彦（1994）: 保護林制度における生物群集の保全の現 状：造園雑誌 57(5), 193-198

157）安井さち子・上条隆志・繁田真由美・ 佐藤洋司（2000）: 栃木県におけるヒメ ホオヒゲコウモリ Myotis ikonnikovi Ognevの分布と現存植生図を用いた分 布の解析：哺乳類科学 40(2), 155-165 